\title{
UPAYA MENINGKATKAN PEMAHAMAN KONSEP MATEMATIKA MENGGUNAKAN PENDEKATAN SAINTIFIK DENGAN MODEL PEMBELAJARAN THINK PAIR SQUARE SHARE (TPSS) PADA POKOK BAHASAN POLINOMIAL DI KELAS XI IPA 3 SMA NEGERI 5O JAKARTA
}

Evan Setiyady Priyatna ${ }^{1, a)}$, Anton Noornia ${ }^{2, b)}$, Dwi Antari Wijayanti ${ }^{3, c)}$

${ }^{123}$ Universitas Negeri Jakarta

Email: ${ }^{\text {a) }}$ evan.setiyady@gmail.com, ${ }^{\text {b) }}$ antonnoornia@yahoo.com, ${ }^{c}$ dwi.antari01@gmail.com

\begin{abstract}
Abstrak
Berdasarkan hasil observasi dan hasil tes kemampuan awal pemahaman konsep matematika yang dilakukan di kelas XI IPA 3 SMA Negeri 50 Jakarta, dapat dikatakan bahwa kemampuan pemahaman konsep matematika siswa masih tergolong rendah, sehingga kemampuan tersebut perlu ditingkatkan. Penerapan pendekatan saintifik dengan model pembelajaran Think Pair Square Share (TPSS) dapat dijadikan sebagai salah satu alternatif dalam pelaksanaan pembelajaran di kelas. Tujuan dari penelitian ini adalah untuk meningkatkan kemampuan pemahaman konsep matematika siswa kelas XI IPA 3 SMA Negeri 50 Jakarta melalui penerapan pendekatan saintifik dengan model pembelajaran Think Pair Square Share (TPSS). Penelitian ini merupakan penelitian tindakan kelas (classroom action research) yang dilaksanakan dalam tiga siklus, setiap siklus terdiri dari empat tahapan, yaitu: perencanaan, pelaksanaan, pengamatan, dan refleksi. Pembelajaran di setiap siklus dengan menerapkan pendekatan saintifik dengan model pembelajaran TPSS. Siswa diberikan tes akhir siklus untuk mengukur kemampuan pemahaman konsep matematika siswa. Penelitian ini berlangsung dari bulan Oktober hingga November 2016 di kelas XI IPA 3 SMA Negeri 50 Jakarta tahun ajaran 2016/2017 dengan jumlah siswa di kelas sebanyak 36 orang siswa. Hasil penelitian menunjukkan bahwa penerapan pendekatan saintifik dengan model pembelajaran Think Pair Square Share (TPSS) dapat meningkatkan kemampuan pemahaman konsep matematika siswa. Hal tersebut ditunjukkan dengan adanya peningkatan nilai rata-rata tes kemampuan pemahaman konsep matematika yang diberikan setiap akhir siklus. Rata-rata nilai kemampuan pemahaman konsep matematika siswa kelas XI IPA 3 pada penelitian pendahuluan adalah 38,03, pada siklus I meningkat menjadi 61,67, pada siklus II meningkat menjadi 80,18 dan pada siklus III meningkat menjadi 92,22. Jumlah siswa yang mencapai atau melebihi nilai 75 yang menjadi kriteria ketuntasan minimal (KKM) pada tes akhir siklus juga mengalami peningkatan. Pada penelitian pendahuluan terdapat 1 siswa $(2,78 \%)$, pada siklus I meningkat menjadi 5 siswa (13,89\%), pada siklus II meningkat menjadi 26 siswa (72,22\%), dan pada siklus III meningkat menjadi 34 siswa $(94,44 \%)$.
\end{abstract}

Kata kunci : Pemahaman Konsep Matematika, Pendekatan Saintifik, Think Pair Square Share 


\section{PENDAHULUAN}

Pendidikan adalah usaha manusia untuk membina kepribadiannya sesuai dengan nilai-nilai di dalam masyarakat dan kebudayaan (Hasbullah, 2006). Istilah pendidikan atau pedagogie dalam perkembangannya, berarti bimbingan atau pertolongan yang diberikan dengan sengaja oleh orang dewasa agar ia menjadi dewasa. Secara mendasar, tujuan dari pendidikan adalah untuk memanusiakan manusia muda demi mencapai tingkat kedewasaan yang lebih tinggi. Artinya, pendidikan berperan untuk menciptakan seseorang yang dapat bertanggung jawab terhadap diri sendiri secara biologis, psikologis, pedagogis dan sosiologis. Peran pendidikan sangat penting dalam mengembangkan kognitif dan karakter agar tercipta sumber daya manusia yang berkualitas. Salah satu lembaga formal pendidikan adalah sekolah, tempat berlangsungnya kegiatan belajar mengajar. Selama proses pembelajaran di sekolah, siswa sebagai peserta didik memerlukan bimbingan yang diberikan oleh guru. Oleh karena itu, guru selalu dituntut untuk dapat menciptakan proses pembelajaran yang baik sehingga mampu menghasilkan siswa yang memiliki pengetahuan yang baik pula.

Metode yang digunakan guru untuk menciptakan proses pembelajaran yang baik sangat beragam. Menurut Ahmadi (2014), metode pembelajaran merupakan salah satu komponen dalam pembelajaran yang penting. Melalui penerapan metode yang tepat, pembelajaran akan berlangsung secara efektif dan sebaliknya jika penggunaan metode tidak tepat bisa berpengaruh negatif pada pembelajaran. Pendapat di atas menjadi penguatan bahwa guru memegang peranan yang sangat penting dalam pembelajaran.

Salah satu mata pelajaran yang selalu ada di sekolah adalah matematika. Matematika merupakan salah satu cabang ilmu pengetahuan yang memiliki peran penting bagi cabang ilmu lain. Matematika merupakan suatu pelajaran yang tersusun secara beraturan, logis, berjenjang dari yang paling mudah hingga yang paling rumit 9 (Dedy Siswoyo, 2013). Salah satu karakteristik matematika adalah mempunyai objek kajian yang bersifat abstrak. Sifat abstrak ini menyebabkan banyak siswa mengalami kesulitan dalam menghayati dan memahami konsep-konsep dalam pelajaran matematika.

Memahami konsep dari sesuatu yang sedang dipelajari merupakan hal yang penting. Menurut Sanjaya dalam Dedi, Pemahaman konsep adalah kemampuan siswa yang berupa penguasaan sejumlah materi pelajaran, tetapi mampu mengungkapkan kembali dalam bentuk lain yang mudah dimengerti, memberikan interprestasi data dan mampu mengaplikasi konsep yang sesuai dengan struktur kognitif yang dimilikinya. Oleh karena itu, seharusnya guru tidak hanya mengajari siswa bagaimana memakai rumus dalam matematika, namun guru harus membuat siswa mengerti tiap konsep yang ada di pelajaran matematika. 
Uraian di atas secara jelas memaparkan betapa pentingnya kemampuan pemahaman konsep matematika siswa dalam pembelajaran matematika, namun pada kenyataannya banyak siswa yang masih belum bisa memahami konsep dalam pembelajaran matematika. Hal ini juga ditemukan pada siswa kelas XI IPA 3 SMA Negeri 50 Jakarta setelah dilakukan observasi kelas pada bulan Oktober dan tes pendahuluan penelitian pada hari Senin, 31 Oktober 2016. Tes tersebut dilakukan untuk melihat tingkat kemampuan pemahaman konsep matematika siswa. Tes berisi empat soal matematika dengan materi trigonometri, persamaan linier, statistic, dan sistem persamaan linier. Siswa kelas XI IPA 3 SMA Negeri 50 Jakarta berjumlah 36 orang. Dua orang siswa tidak masuk dan tidak dapat mengikuti tes pendahuluan penelitian. Dari 34 siswa yang mengikuti tes, diperoleh nilai rata-rata yaitu 38,03 (dalam hal ini penskoran menggunakan skala 0-100). Nilai tertinggi, yaitu 80 hanya diperoleh satu siswa. Sedangkan nilai terendah, yaitu 6,67 diperoleh satu siswa. Dari 34 siswa, hanya satu orang yang nilainya mencapai Kriteria Ketuntasan Minimum (KKM).

Sebelumnya juga dilakukan wawancara dengan guru kelas yang mengampu pelajaran matematika peminatan di kelas XI IPA 3 SMA Negeri 50 Jakarta. Berdasarkan hasil wawancara tersebut, didapatkan informasi bahwa siswa nampak ragu dan kurang aktif untuk belajar matematika sehingga tidak terbentuk pemahaman konsep matematika yang baik sebagai dasar dalam belajar matematika. Guru juga masih kesulitan menerapkan strategi pembelajaran sesuai dengan tuntutan Kurikulum 2013 dan mendapatkan sumber belajar yang cocok sehingga guru banyak mendapatkan sumber dari siswa yang kadang menyimpang dari materi yang dipelajari. Selain itu, siswa sulit mengerjakan soal matematika yang tingkatan soal di atas contoh soal yang diberikan guru.

Berdasarkan hasil tes pendahuluan penelitian dan wawancara dengan guru, didapatkan informasi bahwa siswa mengalami kesulitan dalam mendapatkan dan mengingat konsep dalam pembelajaran matematika. Siswa cenderung mengenal rumus tanpa memahami penerapannya dalam menyelesaikan masalah, sehingga banyak terjadi kesalahan konsep dan jawaban dalam penyelesaian masalah matematika. Berdasarkan informasi-informasi ini, dapat disimpulkan bahwa kemampuan pemahaman matematika siswa masih sangat rendah.

Guru harus lebih kreatif dalam melaksanakan pembelajaran di kelas. pada pendekatan saintifik terdapat tahap mencoba dan mengomunikasikan. Tahap ini guru dapat mengombinasikan dengan metode diskusi yang efektif. Salah satu metodenya yaitu dengan pembelajaran kooperatif model Think Pair Square Share (TPSS), yang dalam Bahasa Indonesia diterjemahkan sebagai Berpikir Berpasangan Berempat Berbagi. Model TPSS ini terdiri atas empat tahap, yaitu siswa mengerjakan masalah dengan kemampuannya sendiri, siswa berdiskusi berpasangan, siswa berdiskusi dengan kelompoknya (terdiri atas empat orang), dan siswa berbagi dengan teman sekelas. Menerapkan pendekatan saintifik dengan menambahkan tahapan TPSS ini pendekatan saintifik diharapkan menjadikan siswa lebih memahami konsep dari materi yang 
dipelajari. Penerapan pendekatan santifik dengan model TPSS dalam pembelajaran matematika tidak mengindikasikan bahwa siswa dilepas untuk membangun pemahaman mereka, namun dalam hal ini guru berperan sebagai fasilitator, mediator, dan manager dalam proses pembelajaran. Berdasarkan pemaparan di atas, Maka diadakan penelitian ini yang berjudul "Upaya Meningkatkan Pemahaman Konsep Matematika Menggunakan Pendekatan Saintifik dengan Model Pembelajaran Think Pair Square Share (TPSS) pada Pokok Bahasan Suku Banyak Di Kelas XI IPA 3 SMA Negeri 50 Jakarta”.

\section{KAJIAN PUSTAKA}

\section{Pemahaman Konsep Matematika}

Menurut Sudijono dalam Lida (2017), Pemahaman adalah kemampuan seseorang untuk mengerti atau memahami sesuatu setelah sesuatu itu diketahui dan diingat. Lalu menurut Ahmad (2013), pemahaman (understanding) adalah kemampuan menjelaskan suatu situasi dengan kata-kata yang berbeda dan dapat menginterpretasikan atau menarik kesimpulan dari tabel, data, grafik, dan sebagainya. Sedangkan menurut Abdulah (2009), Pemahaman bersifat dinamis dan kreatif, sehingga diharapkan menghasilkan imajinasi dan pikiran yang jernih dan tenang. Dengan kata lain, memahami adalah mengetahui tentang sesuatu dan dapat melihatnya dari berbagai segi. Seorang peserta didik dikatakan memahami sesuatu apabila dia dapat memberikan penjelasan atau uraian yang lebih rinci dengan menggunakan kata-katanya sendiri.

Adapun indikator pemahaman konsep matematika menurut Peraturan Dirjen Dikdasmen Nomor 506/C/Kep/PP/2004 tanggal 11 November 2001, yaitu: a). Menyatakan ulang sebuah konsep; b). Mengklasifikasikan objek menurut tertentu sesuai dengan konsepnya; c). Memberikan contoh dan bukan contoh dari suatu konsep; d). Menyajikan konsep dalam berbagai bentuk representasi; e). Menggunakan dan memanfaatkan serta memilih prosedur atau operasi tertentu; F). Mengaplikasikan konsep atau algoritma dalam pemecahan masalah. G). Mengembangkan syarat perlu atau syarat cukup dari suatu konsep. Sedangkan indikator pemahaman konsep matematika menurut Kilpatrick, Swafford, dan Findell yang dikutip oleh Setiadi bahwa indikator pemahaman konsep matematika yaitu, siswa mampu: a). menyatakan ulang konsep yang telah dipelajari; b). memberikan contoh dan bukan contoh dari konsep; c). mengklasifikasikan objek-objek berdasarkan dipenuhi atau tidaknya persyaratan untuk membentuk suatu konsep; d). menyajikan konsep dalam berbagai bentuk representasi matematika; e). menerapkan konsep secara algoritma; f). mengaitkan berbagai konsep (di dalam dan di luar matematika).

Berdasarkan pengertian pemahaman konsep matematika dan indikator pemahaman konsep diatas maka indikator pemahaman konsep yang digunakan dalam penelitian ini mengambil indikator adalah sebagai berikut: a. Menyatakan ulang sebuah konsep. b. Mengklasifikasikan objek menurut tertentu sesuai dengan konsepnya. c. Memberikan contoh dan bukan contoh dari suatu konsep. d. Menyajikan konsep dalam berbagai bentuk representasi. e. Mengaplikasikan konsep atau algoritma dalam pemecahan masalah. 


\section{Think-Pair-Square-Share (TPSS)}

Model pembelajaran kooperatif Think Pair Square Share merupakan pengembangan dari teknik Think Pair Share dan teknik Think Pair Square. Think Pair Share adalah metode yang sederhana tetapi bermanfaat yang dikembangkan oleh Frank Lyman dari Universitas Maryland pada tahun 1985.

Sedangkan Think Pair Square dikembangkan oleh Spancer Kagan dan merupakan pengembangan dari tipe Think Pair Share (Lestari, 2015). Teknik Think Pair Square Share merupakan gabungan dari dua teknik sebelumnya. Teknik ini menambahkan tahap share pada teknik Think Pair Square sehingga ada diskusi kelas yang lebih mendalam. Teknik Think-Pair-Square-Share dalam bahasa Indonesia diterjemahkan sebagai Berpikir-Berpasangan-Berempat-Berbagi Ide (Yunilda, 20017).

Think-Pair-Square-Share terdiri atas empat tahap, yaitu:

a. Siswa mengerjakan masalah dengan kemampuannya sendiri.

b. Siswa berdiskusi berpasangan.

c. Siswa berdiskusi dengan kelompoknya (terdiri atas empat orang).

d. Siswa berbagi dengan teman sekelas.

Siswa dikelompokkan secara heterogen, baik dari segi kemampuan akademik maupun jenis kelamin.

\section{Pendekatan Saintifik dengan Model Think Pair Square Share}

Pendekatan saintifik merupakan salah satu pendekatan pembelajaran yang dapat mengubah pola pembelajaran peserta didik yang pasif menjadi aktif adalah pendekatan saintifik atau ilmiah. Pendekatan saintifik terdiri dari lima tahap pada umumnya, yaitu mengobservasi atau mengamati, menanya, menalar, mencoba atau menyimpulkan, dan mengomunikasikan. Lima tahap ini membuat siswa lebih mandiri dan aktif dalam proses pembelajaran. Pendekatan saitifik dapat dikombinasikan dengan metode diskusi yang efektif. Salah satu metodenya yaitu dengan pembelajaran kooperatif model Think Pair Square Share (TPSS), yang dalam Bahasa Indonesia diterjemahkan sebagai Berpikir Berpasangan Berempat Berbagi. Model TPSS ini terdiri atas empat tahap, yaitu siswa mengerjakan masalah dengan kemampuannya sendiri, siswa berdiskusi berpasangan, siswa berdiskusi dengan kelompoknya (terdiri atas empat orang), dan siswa berbagi dengan teman sekelas. Adapun penerapan pendekatan saintifik dengan menambahkan tahapan TPSS ini adalah sebagai berikut:

a. Tahap think (mengamati): siswa berpikir secara mandiri mengenai pertanyaan atau masalah yang diberikan guru. Siswa mengobservasi materi yang dibutuhkan secara mandiri

b. Tahap pair (mengamati dan menanya): siswa berdiskusi berpasangan dengan teman sebangkunya. Setiap siswa saling mengobservasi, menanyakan, dan membandingkan jawaban dengan teman sebelahnya. Guru mulai berkeliling untuk memantau dan membimbing pekerjaan siswa. 
c. Tahap square (menalar dan mencoba): Setiap pasangan berdiskusi dan berbagi hasil pemikiran mereka dengan pasangan lain dalam satu kelompok (berempat). Siswa berdiskusi sambil mengumpulkan semua pekerjaan yang ada dalam satu kelompok. Kemudian siswa bernalar dengan data yang ada. Setelah itu tiap kelompok mencoba menuliskan jawaban kelompok untuk nanti dipresentasikan.

d. Tahap share (mengomunikasikan): Siswa berbagi dengan teman sekelas. Tahap ini menuntut siswa untuk mengomunikasikan jawaban kelompok mereka. Guru memberi kesempatan atau menunjuk satu kelompok untuk mempresentasikan jawaban mereka. Pada tahap ini jawaban akhir didiskusikan bersama-sama dalam satu kelas.

\section{METODE PENELITIAN}

Penelitian ini merupakan penelitian kualitatif. Jenis penelitian ini adalah penelitian tindakan atau dikenal dengan Action Research, spesifikasi dari penelitian tindakan ini adalah Penelitian Tindakan Kelas (PTK) atau Classroom Action Research. Guru bekerja melakukan pengamatan bersama participant observer, merencanankan tindakan, mengumpulkan dan menganalisis data, serta melaporkan hasil penelitian. Penelitian ini akan dilaksanakan di SMA Negeri 50 Jakarta yang berlokasi di Jalan PLN Cipinang Muara, Jatinegara, Jakarta Timur, DKI Jakarta. Penelitian ini dilaksanakan kepada seluruh siswa kelas XI IPA 3 SMA Negeri 50 Jakarta pada semester ganjil tahun ajaran 2016/2017.

Untuk mempermudah proses penelitian, khususnya dalam memperoleh data berbentuk wawancara, maka dipilih enam orang siswa yang terdiri dari dua orang siswa kelompok atas, dua orang siswa kelompok tengah, dan dua orang siswa kelompok bawah. Pengelompokan yang disebutkan dilakukan berdasarkan peringkat siswa di kelas dan nilai tes penelitian pendahluan matematika sebelumnya. 


\section{Desain Penelitian}

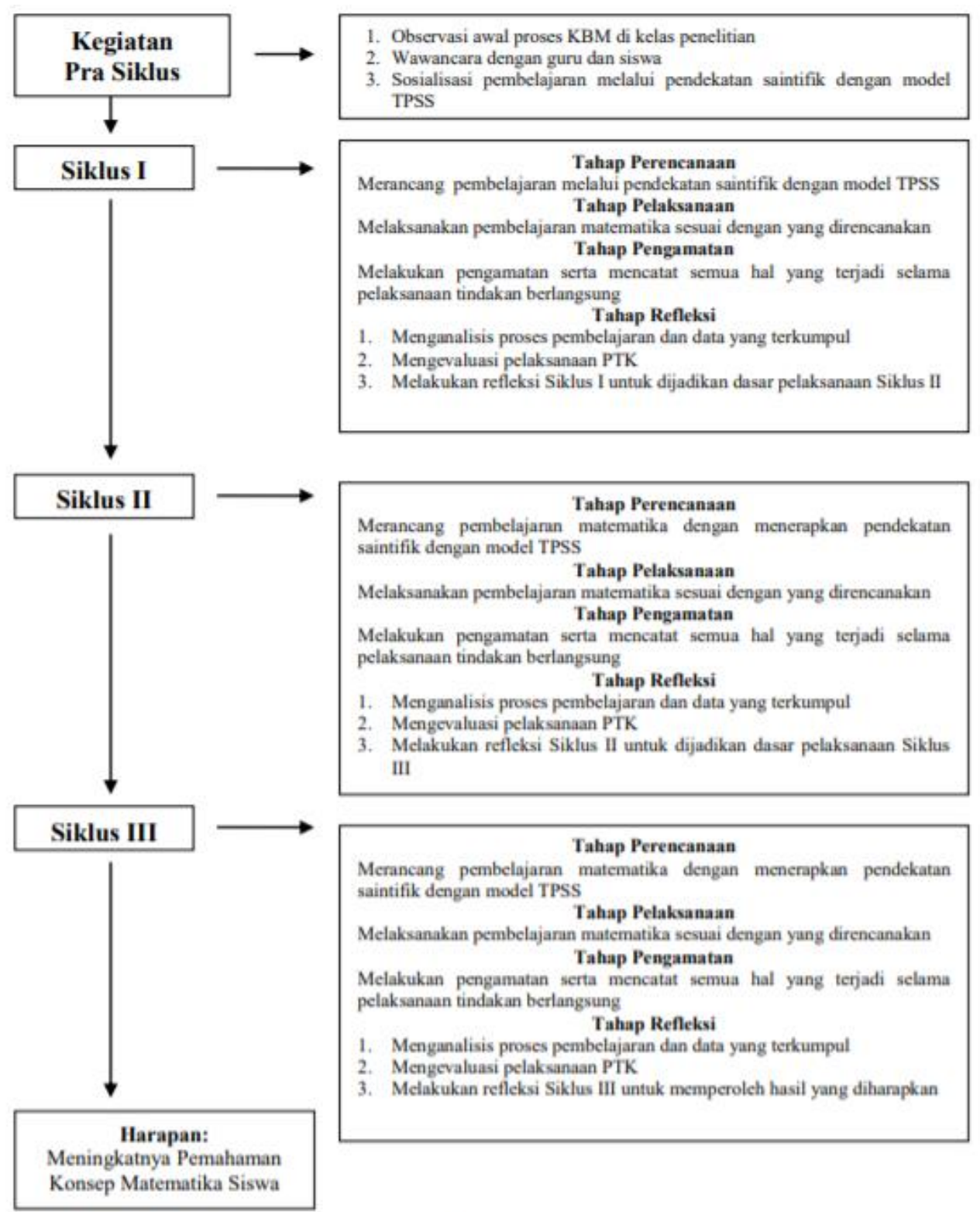

Gambar 3.1. Desain Penelitian

\section{HASIL DAN PEMBAHASAN}

\section{Pra Tindakan Kelas}

Berdasarkan pengamatan yang telah dilakukan selama prasiklus, terlihat suasana kelas masih kurang kondusif. Terdapat banyak siswa yang kurang memerhatikan mahasiswa, dan masih mengobrol dengan siswa lain dikarenakan ketidakhadiran guru dalam kelas. Siswa masih belum memahami penjelasan mahasiswa tentang model TPSS secara keseluruhan. Mahasiswa juga kekurangan waktu sehingga belum sempat melakukan simulasi model TPSS dalam pembelajaran. Berdasarkan pelaksanaan prasiklus, diperoleh beberapa hal yang harus dilakukan untuk pelaksanaan siklus I, yaitu: 1) Guru perlu hadir dalam setiap tahapan penelitian. 2) Kelas harus 
dikondisikan terlebih dahulu sebelum mulai pelajaran atau pembahasan. 3) Guru perlu membagi waktu dengan baik agar semua proses yang direncanakan terlaksana.

2. Siklus I
a. Perencanaan
b. Pelaksanaan
- Pelaksanaan pembelajaran
- Tes akhir siklus
- Wawancara

c. Analisis

Perolehan nilai tes kemampuan pemahaman konsep matematika siklus I kelas XI IPA 3 dapat dilihat pada tabel berikut.

Tabel 2.1. Perolehan Nilai Tes Kemampuan Pemahaman Konsep Matematika Siklus I

\begin{tabular}{|c|c|c|c|}
\hline $\begin{array}{c}\text { Nilai Tes } \\
\text { Pemahaman } \\
\text { Konsep } \\
\text { Matematika }\end{array}$ & Kategori & Frekuensi & Persentase \\
\hline $80 \leq$ nilai $\leq 100$ & Sangat Baik & 5 & $13,89 \%$ \\
\hline $65 \leq$ nilai $\leq 79,99$ & Baik & 11 & $30,56 \%$ \\
\hline $55 \leq$ nilai $\leq 64,99$ & Cukup & 9 & $25 \%$ \\
\hline $40 \leq$ nilai $\leq 54,99$ & Kurang & 7 & $19,44 \%$ \\
\hline $0 \leq$ nilai $\leq 39,99$ & Kurang Baik & 4 & $11 \%$ \\
\hline
\end{tabular}

Nilai rata-rata $=61,67$

Nilai tertinggi $=86,67$

Nilai terendah $=26,67$

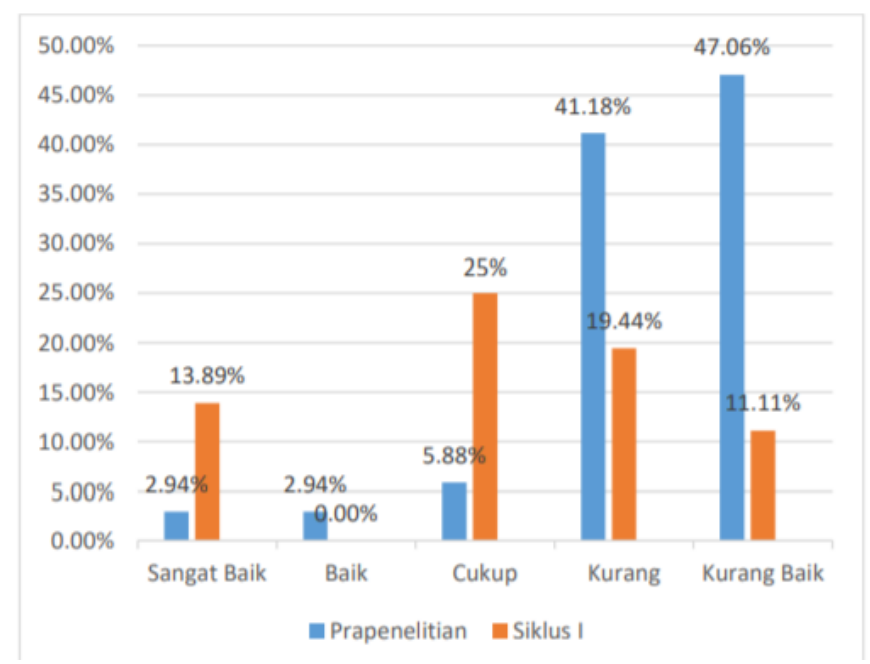

\section{Gambar 2.1. Diagram Peningkatan Persentase Nilai Kemampuan Pemahaman Konsep Matematika pada Prapenelitian dan Siklus I}


Tabel 2.2 Nilai Kemampuan Pemahaman Konsep Matematika Setiap Subjek Penelitian pada Prapenelitian dan Siklus I

\begin{tabular}{|c|c|c|c|c|}
\hline \multirow{2}{*}{$\begin{array}{c}\text { Subjek } \\
\text { Penelitian }\end{array}$} & $\begin{array}{c}|c| \\
\text { Pilai Akhir } \\
\text { Kemampuan } \\
\text { Pemahaman } \\
\text { Konsep } \\
\text { Matematika }\end{array}$ & $\begin{array}{c}\text { Kategori } \\
\text { Kemampuan } \\
\text { Pemahaman } \\
\text { Konsep } \\
\text { Matematika }\end{array}$ & $\begin{array}{c}\text { Nilai Akhir } \\
\text { Kemampuan } \\
\text { Pemahaman } \\
\text { Konsep } \\
\text { Matematika }\end{array}$ & $\begin{array}{c}\text { Kategori } \\
\text { Kemampuan } \\
\text { Pemahaman } \\
\text { Konsep } \\
\text { Matematika }\end{array}$ \\
\hline SP1 & 80 & Sangat Baik & 86.67 & Sangat Baik \\
\hline SP2 & 66.67 & Baik & 73.33 & Sangat Baik \\
\hline SP3 & 53.33 & Cukup & 60 & Cukup \\
\hline SP4 & 26.67 & Kurang Baik & 80 & Sangat Baik \\
\hline SP5 & 33.33 & Kurang Baik & 40 & Kurang \\
\hline SP6 & 20 & Kurang Baik & 66.67 & Baik \\
\hline
\end{tabular}

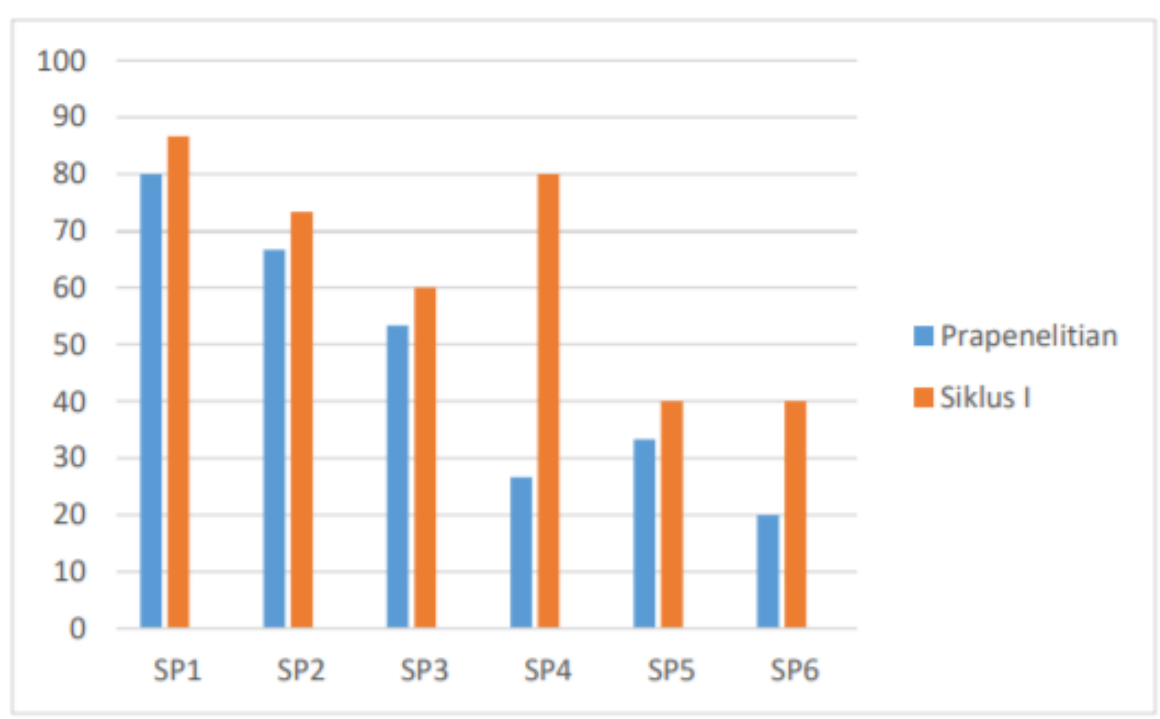

Gambar 2.2. Diagram Peningkatan Nilai Kemampuan Pemahaman Konsep
Matematika pada Setiap Subjek Penelitian pada Prapenelitian dan Siklus I

d. Refleksi

Nilai rata-rata kemampuan pemahaman konsep matematika XI IPA 3 sudah berada pada kategori baik, tetapi nilai kemampuan pemahaman konsep matematika keenam subjek penelitian belum berada pada kategori baik maka perlu diadakan perbaikan pada siklus II.

3. Siklus II

a. Perencanaan

b. Pelaksanaan

- Pelaksanaan pembelajaran

- Tes akhir siklus

- Wawancara 
c. Analisis

Perolehan nilai tes kemampuan pemahaman konsep matematika siklus II kelas XI IPA 3 dapat dilihat pada tabel berikut.

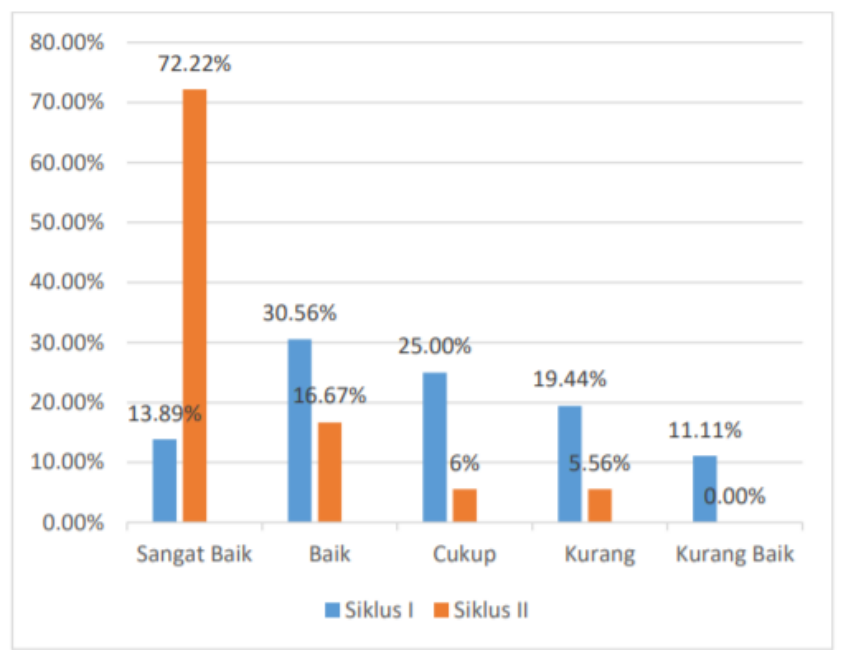

\section{Gambar 3.1 Diagram Peningkatan Persentase Nilai Kemampuan Pemahaman Konsep Matematika pada Siklus I dan Siklus II}

Tabel 3.1 Nilai Kemampuan Pemahaman Konsep Matematika Setiap Subjek Penelitian pada Siklus I dan Siklus II

\begin{tabular}{|c|c|c|c|c|}
\hline \multirow{4}{*}{$\begin{array}{c}\text { Subjek } \\
\text { Penelitian }\end{array}$} & \multicolumn{2}{|c|}{ Siklus I } & \multicolumn{2}{c|}{ Siklus II } \\
\cline { 2 - 5 } & $\begin{array}{c}\text { Nilai Akhir } \\
\text { Kemampuan } \\
\text { Pemahaman } \\
\text { Konsep } \\
\text { Matematika }\end{array}$ & $\begin{array}{c}\text { Kategori } \\
\text { Kemampuan } \\
\text { Pemahaman } \\
\text { Konsep } \\
\text { Matematika }\end{array}$ & $\begin{array}{c}\text { Nilai Akhir } \\
\text { Kemampuan } \\
\text { Pemahaman } \\
\text { Konsep } \\
\text { Matematika }\end{array}$ & $\begin{array}{c}\text { Kategori } \\
\text { Kemampuan } \\
\text { Pemahaman } \\
\text { Konsep } \\
\text { Matematika }\end{array}$ \\
\hline SP1 & 86.67 & Sangat Baik & 86.67 & Sangat Baik \\
\hline SP2 & 73.33 & Baik & 86.67 & Sangat Baik \\
\hline SP3 & 60 & Cukup & 86.67 & Sangat Baik \\
\hline SP4 & 80 & Sangat Baik & 93.33 & Sangat Baik \\
\hline SP5 & 40 & Kurang & 80.0 & Sangat Baik \\
\hline SP6 & 66.67 & Baik & 73.33 & Baik \\
\hline
\end{tabular}

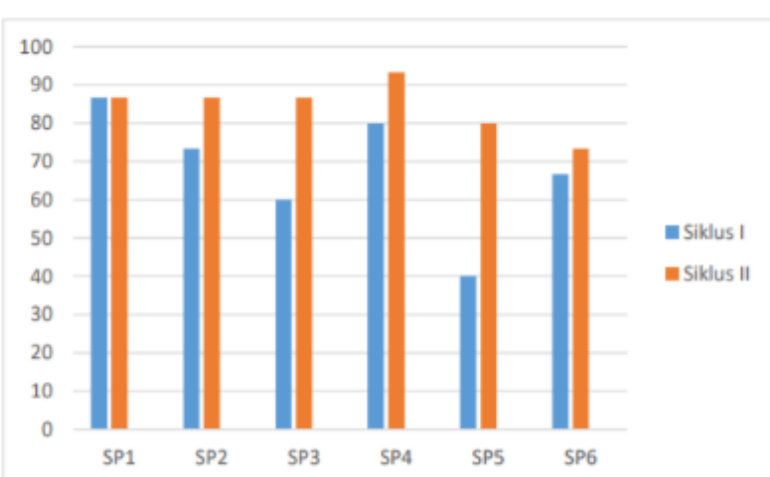

Gambar 3.2 Diagram renıngkatan Ivıaı nemampuan remanaman nonsep ııatematika pada Setiap Subjek Penelitian pada Siklus I dan Siklus II 


\section{d. Refleksi}

Tahapan pembelajaran TPSS sudah terlaksana lebih baik dari sebelumnya tetapi masih ada sedikit kekurangan, maka perlu diadakan perbaikan sedikit lagi pada siklus III

A. Siklus II

a. Perencanaan

b. Pelaksanaan

- Pelaksanaan pembelajaran

- Tes akhir siklus

- Wawancara

c. Analisis

Perolehan nilai tes kemampuan pemahaman konsep matematika siklus II kelas XI IPA 3 dapat dilihat pada tabel berikut.

Tabel 4.1 Perolehan Nilai Tes Kemampuan Pemahaman Konsep Matematika Siklus III

\begin{tabular}{|c|c|c|c|}
\hline $\begin{array}{c}\text { Nilai Tes } \\
\text { Pemahaman } \\
\text { Konsep } \\
\text { Matematika }\end{array}$ & Kategori & Frekuensi & Persentase \\
\hline $80 \leq$ nilai $\leq 100$ & Sangat Baik & 34 & $94.44 \%$ \\
\hline $65 \leq$ nilai $\leq 79,99$ & Baik & 0 & $0 \%$ \\
\hline $55 \leq$ nilai $\leq 64,99$ & Cukup & 1 & $2.78 \%$ \\
\hline $40 \leq$ nilai $\leq 54,99$ & Kurang & 1 & $2.78 \%$ \\
\hline $0 \leq$ nilai $\leq 39,99$ & Kurang Baik & 0 & $0 \%$ \\
\hline
\end{tabular}

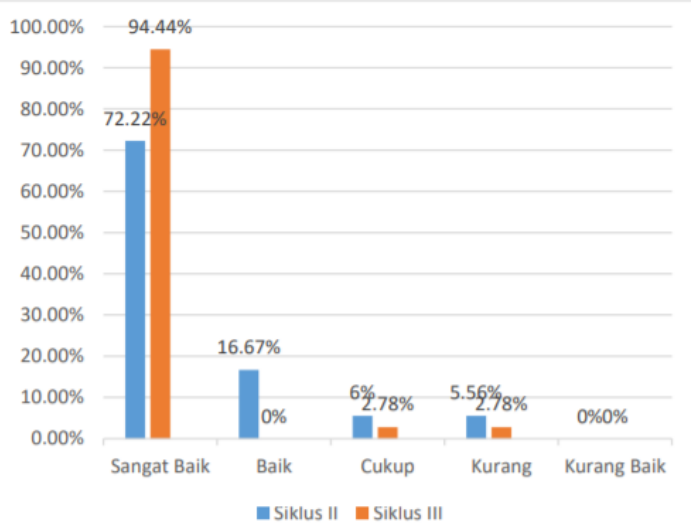

Gambar 4.1 Diagram Peningkatan Persentase Nilai Kemampuan Pemahaman Konsep Matematika pada Siklus II dan Siklus III

\begin{tabular}{|c|c|c|c|c|}
\hline \multirow{4}{*}{$\begin{array}{c}\text { Subjek } \\
\text { Penelitian }\end{array}$} & $\begin{array}{c}|c| \\
\text { Nilai Akhir } \\
\text { Kemampuan } \\
\text { Pemahaman } \\
\text { Konsep } \\
\text { Matematika }\end{array}$ & $\begin{array}{c}\text { Kategori } \\
\text { Kemampuan } \\
\text { Pemahaman } \\
\text { Konsep } \\
\text { Matematika }\end{array}$ & $\begin{array}{c}\text { Nilai Akhir } \\
\text { Kemampuan } \\
\text { Pemahaman } \\
\text { Konsep } \\
\text { Matematika }\end{array}$ & $\begin{array}{c}\text { Kategori } \\
\text { Kemampuan } \\
\text { Pemahaman } \\
\text { Konsep } \\
\text { Matematika }\end{array}$ \\
\hline SP1 & 86,67 & Sangat Baik & 93,33 & Sangat Baik \\
\hline SP2 & 86,67 & Baik & 86,67 & Sangat Baik \\
\hline SP3 & 86,67 & Cukup & 100 & Cukup \\
\hline SP4 & 93,33 & Kurang Baik & 100 & Sangat Baik \\
\hline SP5 & 80 & Kurang Baik & 93,33 & Kurang \\
\hline SP6 & 73,33 & Kurang Baik & 100 & Baik \\
\hline
\end{tabular}




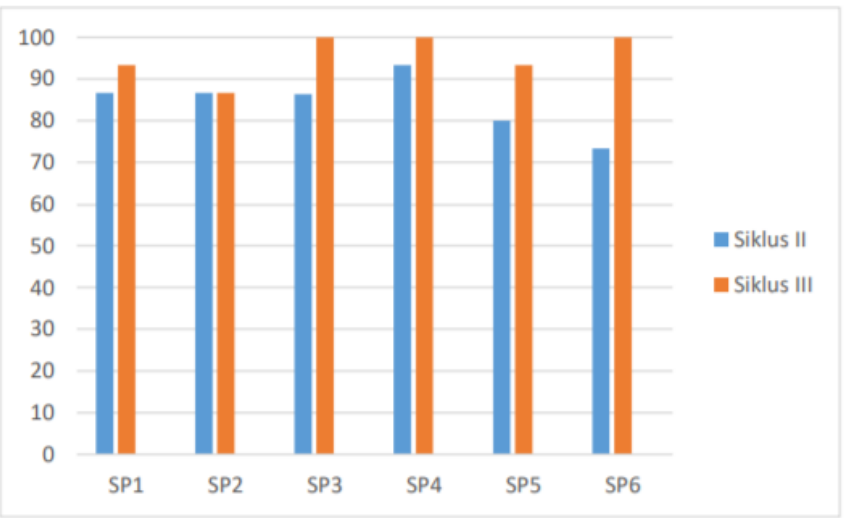

\section{Gambar 4.2 Diagram Peningkatan Nilai Kemampuan Pemahaman Konsep Matematika pada Setiap Subjek Penelitian pada Siklus II dan Siklus III}

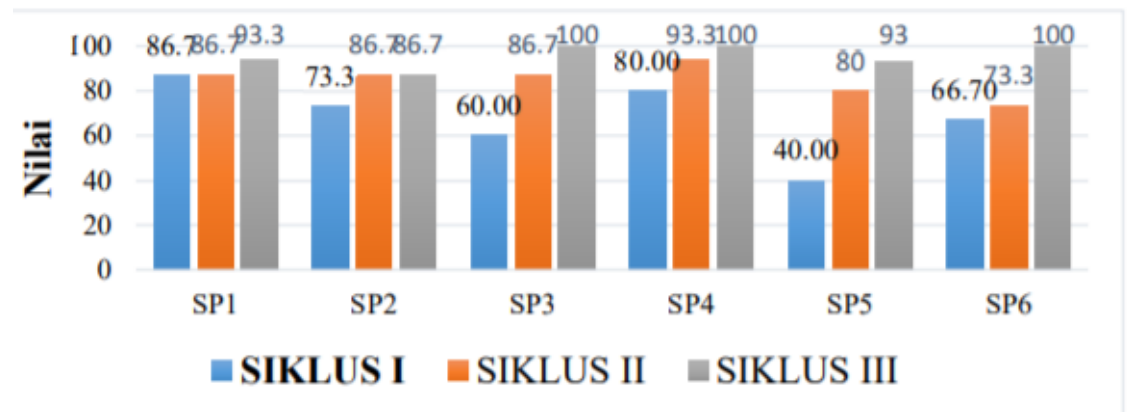

\section{Gambar 4.3 Diagram Peningkatan Nilai Kemampuan Pemahaman Konsep Matematika Seluruh Subjek Penelitian pada Tes Akhir Siklus I, II, dan III}

Pada gambar 4.3 dapat dilihat bahwa seluruh SP meningkat. SP1 pada siklus I sampai siklus III cenderung statis hanya meningkat sedikit namun SP1 sudah mencapai nilai yang tinggi. SP2 meningkat pada siklus I dan II selanjutnya tetap. SP3, SP4, SP5, dan SP6 terlihat terus meningkat pada setiap siklusnya. SP5 dan SP6 meningkat secara signifikan. Berdasarkan hal tersebut dapat dikatakan bahwa penerapan pendekatan saintifik dengan model pembelajaran Think Pair Square Share dapat meningkatkan kemampuan pemahaman konsep matematika siswa dari kelompok berkemampuan rendah (bawah) dan kelompok berkemampuan sedang (tengah) secara maksimal serta mempertahankan kemampuan kelompok berkemampuan tinggi (atas).

\section{SIMPULAN DAN SARAN}

Berdasarkan paparan hasil penelitian di atas, dapat dikatakan bahwa kemampuan pemahaman konsep matematika siswa kelas XI IPA 3 SMA Negeri 50 mengalami peningkatan, baik secara keseluruhan siswa kelas XI IPA 3 maupun keenam subjek penelitian. Nilai rata-rata kemampuan pemahaman konsep matematika siswa kelas XI IPA 3 pada siklus III sudah mencapai target indikator keberhasilan yang telah ditetapkan, yaitu telah mencapai katagori baik, dan jumlah siswa yang mencapai nilai 75 adalah 94,44\%. Berdasarkan hal tersebut, dapat dikatakan bahwa pembelajaran matematika dengan pendekatan saintifik model TPSS sebagai upaya meningkatkan kemampuan pemahaman konsep matematika siswa telah berhasil dalam penerapannya pada penelitian ini. 


\section{DAFTAR PUSTAKA}

Abidin, Yunus. 2014. Desain Sistem Pembelajaran dalam Konteks. Bandung: PT Refika Aditaman. Ahmadi, Rulam. 2014. Pengantar Pendididkan. Yogyakarta: Ar-Ruzz Media Arikunto, Suharsimi. 2009. Penelitian Tindakan Kelas. Jakarta: Bumi Aksara

Daryanto. 2014. Pendekatan Pembelajaran Saintifik Kurikulum 2013. Yogyakarta: Gava Media

Hamalik, Oemar. 2010. Perencanaan Pengajaran Berdasarkan Pendekatan Sistem. Jakarta: PT Bumi Aksara

Hanafiah.2012. Konsep Strategi Pembelajaran. Bandung: PT Refika Aditama Harja. 2012.

Pemahaman Konsep Matematika. [online]

tersedia:http://mediaharja.blogspot.co.id/2012/05/pemahaman-konsep-matematis. html. Diakses tanggal 18 Januari 2015.

Hasbullah. 2006. Dasar-Dasar Ilmu Pendidikan. Jakarta: PT Raja Grafindo Persada Ihsan, Fuad. 2011. Dasar-Dasar Kependidikan. Jakarta: PT Rineka Cipta Komalasari, Kokom. 2010. Pembelajaran Kontekstual: Konsep dan Aplikasi.

Bandung: PT Refika Aditama

Lestari, Doharma. 2015, "Upaya Meningkatkan Kemampuan Komunikasi Matematis Siswa melalui Model Pembelajaran Kooperatif Tipe Think Pair Square (TPS) pada Pokok Bahasan Perbandingan di Kelas VII-D SMP Negeri 99 Jakarta", skripsi, Jakarta: UNJ

Ma'mur. Jamal. 2011. Tuntutan Lengkap Metodologi Praktis Penelitian Pendidikan. Yogyakarta: DIVA Press

Mentari, Lida Ayu. 2013. "Implementasi Metode Resitasi Berbasis Classroom Blogging Untuk Meningkatkan Kemampuan Pemahaman Konsep Siswa". Skripsi. Jakarta: UPI

Siswoyo, Dedi. 2013. Apa itu Matematika?? [online] tersedia: http://dedi26.blogspot.com/2013/02/apaitu-matematika-pengertian.html. Diakses tanggal 21 Desember 2014

Sugeng, Abdulah. 2009. "Perbandingan antara Minat Belajar dan Pemahaman Konsep Matematika Siswa Kelas VII SMP/MTs yang Berasal dari SD/MI yang Menerapkan PMRI dan SD/MI yang Tidak Menerapkan PMRI". Tesis. Yogyakarta: UNY

Sugiyono. 2012. Metode Penelitian Kuantitatif, Kualitatif, dan R\&D. Bandung: Alfabeta

Sumarmo, Utari dan Enung Sumaryati. 2013. "Pendekatan Induktif-Deduktif Disertai Strategi Think-PairSquare-Share untuk Meningkatkan Kemampuan Pemahaman dan Berpikir Kritis serta Disposisi Matematis Siswa SMA". Jurnal Ilmiah, Vol 2, No.1, 26-42.

Susanto, Ahmad. 2013. Teori Belajar dan Pembelajaran di Sekolah Dasar. Jakarta: Prenada Media Group Setiadi, Yudi. 2014. "Meningkatkan Kemampuan Pemahaman dan Komunikasi Matematis Siswa SMP Melalui Pembelajaran Kooperatif dengan Teknik Think-Pair-Square". Tesis. Bandung: UPI 